May $2002 \quad$ N NREL/CP-520-31437

\title{
Identifying Critical Pathways to High Performance PV
}

\section{Preprint}

M. Symko-Davies, R. Noufi, and S. Kurtz

To be presented at the $29^{\text {th }}$ IEEE PV Specialists Conference

New Orleans, Louisiana

May 20-24, 2002

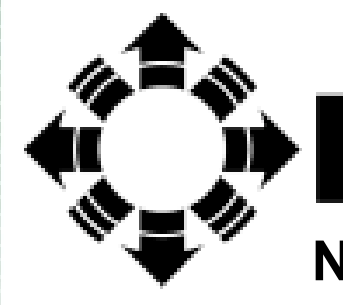

National Renewable Energy Laboratory

1617 Cole Boulevard

Golden, Colorado 80401-3393

NREL is a U.S. Department of Energy Laboratory

Operated by Midwest Research Institute $\bullet$ Battelle $\bullet$ Bechtel

Contract No. DE-AC36-99-G010337 


\section{NOTICE}

The submitted manuscript has been offered by an employee of the Midwest Research Institute (MRI), a contractor of the US Government under Contract No. DE-AC36-99G010337. Accordingly, the US Government and MRI retain a nonexclusive royalty-free license to publish or reproduce the published form of this contribution, or allow others to do so, for US Government purposes.

This report was prepared as an account of work sponsored by an agency of the United States government. Neither the United States government nor any agency thereof, nor any of their employees, makes any warranty, express or implied, or assumes any legal liability or responsibility for the accuracy, completeness, or usefulness of any information, apparatus, product, or process disclosed, or represents that its use would not infringe privately owned rights. Reference herein to any specific commercial product, process, or service by trade name, trademark, manufacturer, or otherwise does not necessarily constitute or imply its endorsement, recommendation, or favoring by the United States government or any agency thereof. The views and opinions of authors expressed herein do not necessarily state or reflect those of the United States government or any agency thereof.

Available electronically at http://www.osti.gov/bridge

Available for a processing fee to U.S. Department of Energy and its contractors, in paper, from:

U.S. Department of Energy

Office of Scientific and Technical Information

P.O. Box 62

Oak Ridge, TN 37831-0062

phone: 865.576 .8401

fax: 865.576.5728

email: reports@adonis.osti.gov

Available for sale to the public, in paper, from:

U.S. Department of Commerce

National Technical Information Service

5285 Port Royal Road

Springfield, VA 22161

phone: 800.553 .6847

fax: 703.605.6900

email: orders@ntis.fedworld.gov

online ordering: http://www.ntis.gov/ordering.htm

Printed on paper containing at least $50 \%$ wastepaper, including $20 \%$ postconsumer waste 


\title{
IDENTIFYING CRITICAL PATHWAYS TO HIGH PERFORMANCE PV
}

\author{
Martha Symko-Davies, Rommel Noufi, and Sarah Kurtz \\ National Center for Photovoltaics (NCPV) \\ National Renewable Energy Laboratory (NREL), Golden, CO
}

\begin{abstract}
The High-Performance Photovoltaic (HiPerf PV)Project was initiated by the U.S. Department of Energy to substantially increase the viability of photovoltaics (PV) for cost-competitive applications so that PV can contribute significantly to our energy supply and our environment in the 21 st century. To accomplish this, the NCPV directs in-house and subcontracted research in high-performance polycrystalline thin-film and multijunction concentrator devices. Details of the subcontractor and in-house progress will be described toward identifying critical pathways of $25 \%$ polycrystalline thin-film tandem cells and developing multijunction concentrator modules to $33 \%$.
\end{abstract}

\section{INTRODUCTION}

The HiPerf PV Project aims at exploring the ultimate performance limits of existing PV technologies, approximately doubling their sunlight-to-electricity conversion efficiencies during its course. This work includes bringing thin-film tandem cells and modules toward $25 \%$ and $20 \%$ efficiencies, respectively; and developing multijunction pre-commercial concentrator modules able to convert more than one-third of the sun's energy to electricity (i.e., 33\% efficiency).

The project consists of three phases that focus on a specific approach to solving the challenges associated with high efficiencies. Phase I, "Identifying Critical Paths," seeks to identify problems, approaches, and alliances. The first HiPerf PV subcontract solicitation [1] completed in 2000 allows the NCPV to provide 2 years of funding to top-ranked companies and universities.

The in-house portion of HiPerf PV is coordinated through three teams. The High Performance Thin-Film Team leads the investigation of tandem structures and low-flux concentrators. The High Efficiency Concepts and Concentrators Team was expanded to lead high-flux concentrator development. The Thin-Film Process Integration Team, will perform fundamental process and characterization research, working toward resolving the complex issues of making thin-film multijunction devices successfully.

The HiPerf PV Project investigates a wide range of complex issues and provides initial modeling and baseline experiments of several advanced concepts to clarify the challenges and identify critical paths for the longer-term development and application of high-performance PV technologies. The first phase is critical as it provides a means to accelerating towards the most promising paths for implementation, followed by commercial-prototype products. These latter efforts constitute the second and third phases of this planned research program. Throughout the life of the project, both revolutionary technology change and multiple incremental improvements will be given their due. During the project period, the alignment of paths, toward established targets and extensive collaboration should produce significant contributions to the entire PV industry.

\section{PROJECT GOALS AND OBJECTIVES}

The HiPerf PV Project is expected to enable progress of high-efficiency technologies towards commercial-prototype products. Table 1 summarizes the near-term key targets for the HiPerf PV Project. These project targets are based on schedules of Phase I awards and planned completion dates of the new Science and Technology Facility.

\begin{tabular}{|l|l|}
\hline \multicolumn{1}{|c|}{ Near-Term Key Targets } & Date \\
\hline $\begin{array}{l}\text { T1. Demonstrate a 20\% Efficiency Thin-Film } \\
\text { Cell under Low Concentration (Completed) }\end{array}$ & 2001 \\
\hline $\begin{array}{l}\text { T2. Identify Key Issues and Pathways to } \\
\text { Achieving a 25\% Polycrystalline Thin-Film } \\
\text { Tandem Cell }\end{array}$ & 2003 \\
\hline $\begin{array}{l}\text { T3. Identify Key Issues and Pathways to } \\
\text { Achieving a 33\% Prototype Concentrator } \\
\text { Module }\end{array}$ & 2003 \\
\hline $\begin{array}{l}\text { T4. Establish Diagnostic Development } \\
\text { Workgroup Towards Implementation of Thin- } \\
\text { Film Process Integration }\end{array}$ & 2003 \\
\hline $\begin{array}{l}\text { T5. Develop Consensus Spectrum Standard } \\
\text { for Measuring Multi-junction Concentrator } \\
\text { Cells }\end{array}$ & 2003 \\
\hline $\begin{array}{l}\text { T6. Demonstrate a multi-junction 34\% Cell } \\
\text { under Concentration }\end{array}$ & 2004 \\
\hline $\begin{array}{l}\text { T7. Fabricate a Polycrystalline Thin-Film } \\
\text { Tandem Cell of 15\% Efficiency }\end{array}$ & 2004 \\
\hline $\begin{array}{l}\text { T8. Full Implementation of Thin-Film } \\
\text { Process Integration }\end{array}$ & 2006 \\
\hline
\end{tabular}

Table 1. Near-Term High Performance PV Project Targets

With regard to Target 2 of Table 1, we are focusing on the development of a wide-band gap top cell with at least $15 \%$ efficiency, optical band gap in the range $1.6 \leq E_{g} \leq 1.8$ $\mathrm{eV}$, and minimal sub-band gap absorption. The wide band gap cell must be identified and developed in advance of other critical issues because the rest of the tandem device 
structure and processing will be determined largely by the choice of this cell. However, the design structure in terms of monolithical integration or mechanical stacking cannot be disregarded while identifying critical issues.

Recent work by Coutts et al.[2] modeling state-ofthe-art thin-film devices demonstrates that a currentmatched $28 \%$ efficient tandem is possible with a top-cell absorber of $1.7 \mathrm{eV}$ and a bottom-cell absorber of $1.1 \mathrm{eV}$. The calculations are based on assuming that all interfaces are specular, there is no interdiffusion and the top p-type absorber is chalcopyrite.

For Target 3 listed in Table 1, we are investigating device design and development of monolithic, waferbonded, and mechanical stacked structures on different substrates. Additionally, PV concentrator receiver design issues are being addressed, and the design spectrum for spectra are being revisited for appropriate measurement conditions of these multijunction concentrator cells. Recently, three-junction GalnP/GaAs/Ge cell grown by Spectrolab was measured under concentration, and, using the AM1.5 global reference spectrum to have an efficiency of $34 \%$. If a fourth junction, with a band gap of about $1 \mathrm{eV}$, is added to this structure to make a GalnP/GaAs/?/Ge cell, the theoretical efficiency is more than $50 \%$. In the past, world-record efficiencies have reached $80 \%$ to $90 \%$ of theoretical efficiencies, implying that a four-junction concentrator cell will surpass $40 \%$ efficiency if the appropriate material systems can be identified.

\section{SUBCONTRACTOR R\&D}

Ten of eleven awards are completed, and, we are well into Phase I of Identifying Critical Pathways. The in-house and subcontracted research activities are beginning to work closely together toward achieving project goals. The majority of the subcontracts have scheduled deliverables to NREL for the specific purpose of collaborating with the in-house teams. Table 2 lists the subcontracts currently active in Phase I, beginning with the polycrystalline thin-film awards, followed by the multi-junction concentrator awards, followed by a description of R\&D progress by each subcontractor.

\begin{tabular}{|l|l|}
\hline Subcontractor & Title \\
\hline *Astropower & $\begin{array}{l}\text { InGaP/GaAs-on-Ceramic Thin-Film } \\
\text { Monolithically Interconnected, } \\
\text { Large Area, Tandem Solar Cell Array }\end{array}$ \\
\hline $\begin{array}{l}\text { University of } \\
\text { Delaware }\end{array}$ & $\begin{array}{l}\text { Thin Film Multijunction Solar Cells: } \\
\text { Development of a High-Bandgap Cell }\end{array}$ \\
\hline $\begin{array}{l}\text { University of } \\
\text { Toledo }\end{array}$ & $\begin{array}{l}\text { Polycrystalline Thin-Film Tandem } \\
\text { Photovoltaic Cells }\end{array}$ \\
\hline $\begin{array}{l}\text { University of } \\
\text { South Florida }\end{array}$ & $\begin{array}{l}\text { Development of a II-VI-Based High } \\
\text { Performance, High Band Gap Device } \\
\text { for Thin-Film Tandem Solar Cells }\end{array}$ \\
\hline
\end{tabular}

\begin{tabular}{|l|l|}
\hline $\begin{array}{l}\text { University of } \\
\text { Florida }\end{array}$ & $\begin{array}{l}\text { Identification of Critical Paths in the } \\
\text { Manufacturing of Low-Cost High- } \\
\text { Efficiency CGS/CIS Two-Junction } \\
\text { Tandem Cells }\end{array}$ \\
\hline Global Solar & $\begin{array}{l}\text { Progress Toward 20\% Efficient } \\
\text { Culn } \mathrm{Ga}_{1-\mathrm{x}} \text { Se }_{2} \text { Photovoltaic Devices } \\
\text { on Foil Substrates }\end{array}$ \\
\hline $\begin{array}{l}\text { University of } \\
\text { Illinois }\end{array}$ & $\begin{array}{l}\text { Cu(In,Ga)Se Heterojunction Solar } \\
\text { Cells for Extreme High-Efficiency } \\
\text { Photovoltaic Concentrators }\end{array}$ \\
\hline Entech, Inc. & $\begin{array}{l}\text { Near-Term Integration of III-V Cells } \\
\text { Operating at 440X, Into Entech's } \\
\text { Field-Proven Concentrator Module }\end{array}$ \\
\hline $\begin{array}{l}\text { SunPower } \\
\text { Corporation }\end{array}$ & $\begin{array}{l}\text { Lens-Based Concentrator Modules: } \\
\text { Exploring Critical Optical and System } \\
\text { Integration Issues }\end{array}$ \\
\hline $\begin{array}{l}\text { Spectrolab, } \\
\text { Inc. }\end{array}$ & $\begin{array}{l}\text { High Efficiency, Low-Cost, III-V } \\
\text { Concentrator PV Cell \& Receiver } \\
\text { Module }\end{array}$ \\
\hline Emcore & $\begin{array}{l}\text { A Three-Junction Solar Cell for High- } \\
\text { Concentration Applications }\end{array}$ \\
\hline
\end{tabular}

Table 2. Polycrystalline Thin Film Tandem Cell Subcontractor R\&D ( ${ }^{*}$ currently under negotiation)

\section{Polycrystalline Thin-Film Tandem Cell Subcontractors}

The University of Delaware is using two approaches to develop a polycrystalline thin-film tandem cell. The first approach, to design and construct a new system for elemental evaporation of $\mathrm{Cu}(\operatorname{InGa})(\mathrm{SeS})_{2}$, has been completed. Good spatial uniformity, with less than $10 \%$ thickness variation was demonstrated for the metal sources. The first $\mathrm{Cu}(\mathrm{InGa}) \mathrm{Se}_{2}$ films have now been deposited, and procedures for simultaneous control of the Se and S will be implemented. The second approach is to develop $\mathrm{Cd}_{1}$. ${ }_{x} \mathrm{Zn}_{\mathrm{x}}$ Te thin-film solar cells. Evaporation from independently controlled $\mathrm{CdTe}$ and $\mathrm{ZnTe}$ sources allows excellent composition control, and films have been deposited over the complete composition range $0 \leq x \leq 1$. Broadening of $x$-ray diffraction peaks and a change in surface morphology, including a decrease in grain size, suggest that a degree of disorder exists within the alloy films compared to CdTe or $\mathrm{ZnTe}$ films. CdS/Cd $\mathrm{C}_{1-\mathrm{x}} \mathrm{Zn}_{\mathrm{x}}$ Te solar cells have been fabricated without post-deposition treatment and had single-phase composition prior to treatment.

The University of Florida is working toward identifying critical issues associated with the design and manufacture of a monolithic two-junction tandem cell consisting of a CIS bottom cell and a CGS top cell connected via a heavilydoped tunnel junction. Recently, the carried out numerical simulation studies of a CuGaSe $\mathrm{CulnSe}_{2}$ two-junction tandem solar cell using the AMPS-1D program. The results 
predict that an efficiency of $25 \%$ is realizable for an optimized four-terminal tandem cell. The analysis considered bottom-cell thickness values ranging from 200 $\mathrm{nm}$ to $2000 \mathrm{~nm}$. Additionally, they studied the quantum efficiency (QE) curves for the CGS top cell and CIS bottom cell. The simulation efficiencies were $15.65 \%$ and $8.36 \%$ for the CGS $(1400 \mathrm{~nm})$ top and CIS $(2000 \mathrm{~nm})$ bottom cells, respectively, yielding a total tandem composite efficiency of $24.01 \%$. Values of $\mathrm{Jsc}$ were 17.20 and $21.08 \mathrm{~mA} / \mathrm{cm}^{2}$ for the CGS $(1400 \mathrm{~nm})$ top and CIS $(2000 \mathrm{~nm})$ bottom cells, respectively.

The University of Toledo is looking to optimize back contacts to CdTe that are based on reactively sputtered ZnTe:N. To be used as a back contact with a CdTe or $\mathrm{CdZnTe}$ top cell, this contact must be transparent to photons of energy below the top-cell band gap. Unfortunately, the conductivity of $\mathrm{p}-\mathrm{ZnTe} \mathrm{N}$ is typically a few Ohm-cm and, therefore, is much too resistive to use with a metal grid structure. Thus, they have usually used the ZnTe:N together with a final continuous layer of nickel which serves as a functional, copper-free back contact to a singlejunction CdTe device. They have succeeded in utilizing sputtered $\mathrm{ZnO}: \mathrm{Al}$ to replace the $\mathrm{Ni}$, which maintains the transparency while giving the high lateral conductivity needed for the grid structure suitable for the top cell in a four-terminal tandem structure. Furthermore, because the $\mathrm{ZnO}: \mathrm{Al}$ is already used for top contacts in CIS cells, it suggests that this structure should be able to function as a recombination layer in two-terminal tandem cells with a CdZnTe top cell and a CIS bottom cell.

The University of South Florida is working on identifying critical issues associated with developing a high-band gap II-VI based device that can serve as the top cell in an allthin-film tandem structure that can achieve an efficiency of $25 \%$. They have been depositing CdZnTe films by cosublimation, referred to as close-spaced co-sublimation. Preliminary results indicate that they can obtain singlephase films with this process as indicated by XRD with $x$ (zinc content) up to $30 \%$. The composition estimated from XRD was also verified with EDS, within $1 \%-2 \%$ in the films that they did compare. Some of the films were also used in "solar cell structures", i.e. glass $/ \mathrm{SnO}_{2} / \mathrm{CdS} / \mathrm{CZT} / g r a p h i t e$, which is essentially the same configuration they use for CdTe. At this time their most positive result is Voc's in excess of $700 \mathrm{mV}$.

Global Solar is working toward improving the efficiency of CIGS devices on metal foils for use with concentrator systems by (1) understanding and eliminating efficiency differences between the best devices on foil and the best devices on glass, and (2) increasing blue light collection through elimination or modification of the CdS layer. They have constructed a research-sized evaporator to fabricate CIGS films in small quantities. The system provides GSE with an avenue to quickly answer questions regarding high performance devices and associated production issues. The small system size, careful rate and temperature monitoring, and use of the NREL three-stage process should allow answering such questions with speed and accuracy not possible when using large-scale production equipment.

\section{Concentrator Subcontractors}

The University of Illinois is examining possible approaches for the use of single crystal epitaxial CIGS as the $1.0 \mathrm{eV}$ energy-gap absorber layer in a four-junction solar cell. Their first approach is growth of epitaxial CIGS on $n+$ GaAs substrates. To date they have obtained substrates with various orientations, and epitaxial layers have been grown. Additionally, the CIGS-GaAs diodes produced show good J/V and photovoltage. The second configuration they are working on is the growth on a Ge substrate.

Spectrolab is working toward achieving an ultra-high efficiency, low-cost III-V solar cell, either through a monolithic structure or by mechanical-stacking or waferbonded integrated cells. Additionally, they are developing a modul- packaging design and process that enable efficient heat management of the solar cells and ensure reliable interconnects under thermal cycling. The ultimate result of this work will be to identify the critical paths towards achieving a $33 \%$ solar conversion module within the cost targets of under $\$ 1 /$ watt.

SunPower's objective is to assess the optical options available for high performance Fresnel lens concentrators. Specifically assessing available lens technologies, new and emerging optic technologies, and key optics-to-cell system integration and reliability issues

ENTECH worked toward designing and developing a full-size, $27 \%$ efficient, $440 X$ concentrator module. This was to include the following developments: $21 \mathrm{X}$ color-mixing primary lens and secondary lens and 33\%-efficient prismcovered triple-junction solar cell operating at 370 suns average irradiance. Additionally, extensive work was conducted on integrating the photovoltaic receiver including heat spreader, cell-to-cell interconnects, bypass diode protection, dielectric isolation, encapsulation, and secondary optics. It was found that adapting the new optics, cells, and receiver technology to it's existing module and sun-tracking array products requires future effort.

Emcore is developing techniques to demonstrate a greater than 40\%, 500x, AM1.5D efficient two-terminal, lattice-mismatched cell. The final cell will have a minimal area of $0.5 \mathrm{~cm}^{2}$ lattice-mismatched $\mathrm{Ga}_{x} \mathrm{In}_{1-x} \mathrm{P} / \mathrm{Ga}_{x} \mathrm{In}_{1-x}$ As dual junction cell on a diffused $\mathrm{Ge}$ junction with the appropriate buffer layer. The developed cells are to be demonstrated and tested in an Amonix concentrator system.

\section{NREL IN-HOUSE R\&D}

\section{In-House Polycrystalline Thin-Film tandem Cells}

The in-house activities concern fundamental studies of the various components of monolithic dual-junction device. Two top-cell materials have been chosen for the initial phase of the research: $\mathrm{CuGaSe}_{2}$ and $\mathrm{Cd}_{x} \mathrm{Zn}_{1-\mathrm{x}} \mathrm{Te}$, with band gap around $1.7 \mathrm{eV}$. The effort has focused on: (1) the growth processes to produce phase pure thin films; and (2) growth on transparent conducting (TC) substrates such as 
$\mathrm{SnO}_{2}$, ITO, etc. for the case of $\mathrm{CuGaSe}_{2}$, and $\mathrm{ZnTe}: \mathrm{Cu}$ transparent contact for $\mathrm{CdZnTe}$. Of significant interest is the optical characterization of the top cell to assess optical resources available to the bottom cell.

The experimental work is being guided by the modeling of two-junction thin film tandem stacks [3]. The model calculates the reverse saturation current density as a function of bandgap by using equivalent data from the best thin-film cells, of known bandgaps, characterized at NREL. The work emphasizes the crucial role that the properties of transparent conductors and the shorting junction have on the overall performance of the device.

To date, most of the effort has been applied to thin-film growth of CGS and CdZnTe to optimize the performance of the top cell. In addition, the team has been investigating a bifacial device structure using $\mathrm{CuGaSe}_{2}$ and $\mathrm{Cu}(\mathrm{In}, \mathrm{Ga}) \mathrm{Se}_{2}$ as the absorber pair on either side of a transparent conducting glass substrate [4].

\section{In-House Concentrator}

The in-house concentrator activities focus on the addition of a 1-eV GalnAsN junction to a GalnP/GaAs/Ge cell. This structure has the potential of reaching efficiencies in the $35 \%-40 \%$ range [5]. The topics being addressed include materials measurements, spectra issues, and stability/degradation issues.

Recent work has shown that the direct reference spectrum is not representative of sunny conditions in regions with a high annual direct-normal energy where concentrators might be deployed (the Sun Belt).A new proposed direct reference spectrum and its effect on the short-circuit current is being investigated by NREL for evaluating III-V concentrator cells [6-8].

Recently, an analysis was completed to estimate the maximum efficiency that is realistically achievable for the GalnP/GaAs/Ge cell under concentration, assuming that all parts of the device, including the front grids, are optimized as well as is practically possible. NREL researchers project achievable 3 junction concentrator cell efficiencies in the $37 \%$ range for the AM1.5G and low-AOD spectra, and in the $35 \%$ range for the AM1.5D spectrum. Increasing the cell size to $1 \mathrm{~cm}^{2}$ lowers projected efficiencies by $\sim 1 \%$.

\section{CONCLUSIONS}

Phase I, Identifying Critical Paths, of the HiPerf PV Project, is underway with in-house and subcontracted research in high-performance polycrystalline thin film's and multijunction concentrator devices. Ten of eleven subcontracts active are making headway.

In pursuit of long-term DOE-goals, the HiPerf PV Project is focused to assure that tandem thin film modules reach efficiency levels consistent with cost-competitive goals, and that concentrator cells reach performance levels that would allow concentrator PV to be deployed appropriately to produce cost-competitive electricity.

\section{ACKNOWLEDGMENTS}

This work is supported under DOE Contract No. DEAC36-99G010337 with NREL. Many people have contributed to the development and implementation of the High Performance PV Project and to the R\&D efforts carried out in this program. The authors thank each of them and recognize that this paper represents their work.

\section{REFERENCES}

[1] V. Riddell and K. Zweibel, "High Performance Photovoltaics, Phase I: Identifying Critical Paths," Solicitation for LOI No. RDJ-0-30620-00, June 2000.

[2] T.J. Coutts, J.S. Ward, D.L. Young, T.A. Gessert, and R. Noufi, "The search for and potential impact of improved transparent conducting oxides on thin-film solar cells," Technical Digest of the 12th. International Photovoltaic Science and Engineering Conference, Jeju, Korea, June 11$15 / 2001$.

[3] T.J. Coutts, K. Emery, and J.S. Ward, "Modeled Performance of Polycrystalline Thin-Film Tandem Cells," Prog. Photovolt: Res. Appl. 2002; 10:195-203.

[4] D.L. Young, J. Abushama, R. Noufi, X. Li, J. Keane, K. Ramanathan, T. Gessert, J. Ward, M. Contreras, M. SymkoDavies, and T. Coutts, "A new Thin-Film CuGaSe ${ }_{2}$ / $\mathrm{Cu}(\mathrm{In}, \mathrm{Ga}) \mathrm{Se}_{2}$ Bifacial, Tandem Solar Cell with Both Junctions Formed Simultaneously," To be presented at the 29th IEEE PVSC, New Orleans, 2002.

[5] S.R. Kurtz, D. Myers, and J. Olson, "Projected Performance of Three- and Four-Junction Devices using GaAs and GalnP," 26th IEEE PVSC, Anaheim, 1997.

[6] K. Emery, D. Myers, and S. Kurtz, "What is the Appropriate Reference Condition for Measuring Concentrator Cells," To be presented at the 29th IEEE PVSC, New Orleans, 2002.

[7] D. Myers, K. Emery, and S. Kurtz," Proposed Reference Spectral Irradiance Standards To Improve Concentrating Photovoltaic System Design and Performance Evaluation Concentrator Cells," To be presented at the 29th IEEE PVSC, New Orleans, 2002.

[8] B. McMahon, S. Kurtz, K. Emery, and M Young, "Criteria for the Design of GalnP/GaAs/Ge Triple-Junction Cells to Optimize their Performance Outdoors," To be presented at the 29th IEEE PVSC, New Orleans, 2002. 


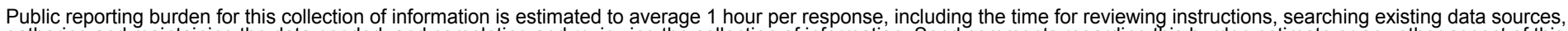

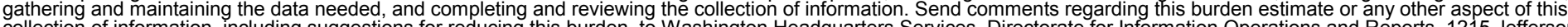
Davis Highway, Suite 1204, Arlington, VA 22202-4302, and to the Office of Management and Budget, Paperwork Reduction Project (0704-0188), Washington, DC 20503.
1. AGENCY USE ONLY (Leave blank)
2. REPORT DATE May 2002
3. REPORT TYPE AND DATES COVERED $29^{\text {th }}$ IEEE PVSC-Conference Paper May 20-24 2002

4. TITLE AND SUBTITLE Identifying Critical Pathways to High Performance PV: Preprint

6. AUTHOR(S) M. Symko-Davies, R. Noufi, and S. Kurtz

7. PERFORMING ORGANIZATION NAME(S) AND ADDRESS(ES) National Renewable Energy Laboratory 1617 Cole Blvd. Golden, CO 80401-3393

9. SPONSORING/MONITORING AGENCY NAME(S) AND ADDRESS(ES) National Renewable Energy Laboratory 1617 Cole Blvd. Golden, CO 80401-3393
5. FUNDING NUMBERS PVP10100
8. PERFORMING ORGANIZATION REPORT NUMBER

11. SUPPLEMENTARY NOTES

12a. DISTRIBUTION/AVAILABILITY STATEMENT

National Technical Information Service

12b. DISTRIBUTION CODE

U.S. Department of Commerce

5285 Port Royal Road

Springfield, VA 22161

13. ABSTRACT (Maximum 200 words): This conference paper describes the High-Performance Photovoltaic (HiPerf PV)Project was initiated by the U.S. Department of Energy to substantially increase the viability of photovoltaics (PV) for cost-competitive applications so that PV can contribute significantly to our energy supply and our environment in the 21 st century. To accomplish this, the NCPV directs in-house and subcontracted research in high-performance polycrystalline thin-film and multijunction concentrator devices. Details of the subcontractor and in-house progress will be described toward identifying critical pathways of $25 \%$ polycrystalline thin-film tandem cells and developing multijunction concentrator modules to $33 \%$.

14. SUBJECT TERMS: PV; high performance PV; sunlight-to-electricity conversion; polycrystalline thin film; multijunction concentrators; tandem cells;

15. NUMBER OF PAGES

16. PRICE CODE

17. SECURITY CLASSIFICATION OF REPORT Unclassified
18. SECURITY CLASSIFICATION OF THIS PAGE Unclassified
19. SECURITY CLASSIFICATION OF ABSTRACT Unclassified
20. LIMITATION OF ABSTRACT

UL 